\title{
Top 100 cited articles in traumatology: A bibliometric analysis
}

\author{
느 Mehmet Dokur, M.D., ${ }^{1}$ Erdal Uysal, M.D. ${ }^{2}$
}

${ }^{1}$ Department of Emergency Medicine, Biruni University Faculty of Medicine, İstanbul-Turkey

${ }^{2}$ Department of General Surgery, Sanko University Faculty of Medicine, Gaziantep-Turkey

\begin{abstract}
BACKGROUND: In this bibliometric study, we aimed to conduct multi-dimensional citation analysis of the top 100 cited articles in traumatology.

METHODS: We analyzed the top 100 cited articles among 56.980 trauma articles published between 1975 and 2017 , which we obtained from databases in Web of Science and PubMed based on their citation rates and publication years, countries of origin, institutions or organizations, the most common subjects, funding status, article types, and levels of evidence.

RESULTS: In the top 100 cited articles, the number of total authors was 649 and average authorship was $6.49 \pm 5.46$ (I-32); group author or study group number was eight, and the number of total collaborators was I24I. USA was the top country in terms of country of origin and institutions or organizations and also the number of proceedings papers in scientific activities. We found that 70 of the top 100 cited articles were supported by funding agencies in developed countries. In the present study, the three most common subjects were central nervous system trauma (2l articles), major trauma-hemorrhage-bleeding control-transfusion-early coagulopathy ( 18 articles), and trauma care and systems (eight articles), respectively. The average level of evidence of the top 100 cited articles was $2.45 \pm 1.05$ (range: $1-4$ ). We also found that 66 of the 100 most frequently cited articles in traumatology were published in scientific journals that had an impact factor of $\geq 2.6$ (range: 2.648-72.406). We found that the most commonly preferred article type by authors is clinical research ( 92 articles) and sub-type is prospective comparative studies ( 27 articles). Evidence groups of classical papers in traumatology were B (54 articles), A (26 articles), and C (20 articles), respectively.
\end{abstract}

CONCLUSION: Despite some flaws in determining the scientific values of articles, citation analysis of classical papers in traumatology can provide important scientific contributions.

Keywords: Articles; bibliometric; top-cited; traumatology.

\section{INTRODUCTION}

Trauma is the most prominent cause of death in children and young people. ${ }^{[1]}$ Approximately 5.8 million people die each year as a result of injuries. This accounts for $10 \%$ of the deaths worldwide. ${ }^{[2]}$ For this reason, traumatic injuries, which are frequently encountered in emergency services and surgical clinics, are important clinical and surgical problems that require a multidisciplinary approach. ${ }^{[3,4]}$ Trauma is generally accepted as preventable mortal and/or morbid problems. However, in a 25-year evaluation, Campbell WB et al. ${ }^{[5]}$ reported that the number of all emergency admissions increased with time, whereas mortality rates and hospitalization time reduced significantly. In this context, traumatology is a subject of study for scientific researches in epidemiological, diagnostic, therapeutic, and prognostic fields. ${ }^{[6,7]}$

Initially, in 1987, Garfield E introduced the concept of "citation classics" for the best-cited articles published in JAMA. In later years, many bibliometric article analyses were conducted in different fields of medicine. ${ }^{[8]}$ Citation analysis of classical or top-cited articles regarding traumatology can significantly contribute to this field in terms of exhibiting up-to-date academic information, progress, and tendencies. However, there

Cite this article as: Dokur M, Uysal E. Top 100 cited articles in traumatology: A bibliometric analysis. Ulus Travma Acil Cerrahi Derg 2018;24:294-302.

Address for correspondence: Mehmet Dokur, M.D.

Biruni Üniversitesi Tıp Fakültesi, Acil Tıp Anabilim Dalı, Beşyol Mah., No: 10, 34295 Florya, İstanbul, Turkey.

Tel: +90 212 - 4113900 / 1008 E-mail: mdokur@biruni.edu.tr

Ulus Travma Acil Cerrahi Derg 2018;24(4):294-302 DOI: 10.5505/tjtes.2017.74857 Submitted: 21.09.2017 Accepted: 13.12.2017 Online: 20.06.2018

Copyright 2018 Turkish Association of Trauma and Emergency Surgery 
are few bibliometric studies related to traumatology in the current literature. ${ }^{[9-1 I]}$ In the present study, we systematically analyzed the top 100 cited articles "key papers or classic papers" according to data obtained from PubMed and Web of Science (WoS) in the field of traumatology. We determined the number of citations with ranking, citations and publications by years, publishing journals, type and sub-type of articles, institutions and countries of origin, the most common topic of frequently cited articles, and authorship status of classical papers in this bibliometric research.

\section{MATERIALS AND METHODS}

\section{Study Design}

Study type: Retrospective clinical research

Level of evidence: 3 or Group B (Scottish Intercollegiate Guidelines Network; SIGN).[12]

\section{Data Collection and Inclusion Criteria}

Data used in this bibliometric citation analysis was obtained from Thomson Reuters' WoS Core Collection database (Philadelphia, Pennsylvania, USA) and PubMed (US National Library of Medicine-National Institutes of Health). We accessed the WoS database (accessed date: 23.03.2017) using the keyword "trauma" between 1975 and 2017. Consequently, we obtained 56.980 articles and conducted analysis of the top 100 cited articles among these results. We accessed the remaining data pertaining to the analyzed articles via PubMed. Two of the authors (M.D. and E.U.) independently identified the top 100 cited articles with consensus.

Being a first author or co-author was accepted as the authorship criterion in the present study. To shorten the obtained table, we limited quantitative values to " 2 or more and 3 or more." The level of evidence of the top 100 cited articles was detected in accordance with SIGN criteria. ${ }^{[2]}$ Accordingly, Group A evidence (levels Ia and Ib) comprised randomized clinical trials (RCT) or meta-analysis of RCT. Group $B$ evidence (levels $2 a, 2 b$, and 3 ) comprised cohort studies, case-control studies, and comparison of two or more groups where data were collected retrospectively, as well as semiexperimental studies. Group C evidence (level 4) comprised case series and expert opinions or expert committee reports (excluding levels I and 3 evidence). Group D evidence (level 5) comprised case reports.

\section{Statistical Analysis}

Descriptive statistical methods were used in the present study. All data are expressed as a percentage, number, bar chart, or mean \pm standard deviation in the tables.

\section{Ethical Statement}

All authors declare that the research was conducted according to the principles of the World Medical Association Declaration of Helsinki "Ethical Principles for Medical Research Involving Human Subjects." This study did not need to be approved by an ethics committee because it performed a bibliometric analysis or citation analysis of existing published classical studies.

\section{RESULTS}

\section{Contributions, Attributions, and Research Groups}

We detected the citation average of the top 100 cited articles in traumatology as 430.06 I 72.7 (range: 257-I 108), and the sum of self-citation was 139 (according to Thomson Reuters' WoS Core Collection). The publishing language was English for all articles. We found that the most cited article (times cited: I 108) in traumatology is the review by Boyd CR et al. on trauma scoring systems with the following topic: "Evaluating trauma care: the TRISS method. Trauma Score and the Injury Severity Score. J Trauma 1987;27:370-8." The least cited article (times cited: 257) in traumatology was another review by Leker RR and Shohami E who studied different etiological approaches on cerebral ischemia and trauma with the following title: "Cerebral ischemia and trauma-different etiologies yet similar mechanisms: neuroprotective opportunities. Brain Res Rev 2002;39: 55-73' (Appendix I). Among the 100 most influential manuscripts, the number of group authors or study groups was eight (CRASH-2 Trial Collaborators with two studies, 39 authors, and II 28 collaborators; Pediatric Emergency Care Applied Research Network with one study, 32 authors, and 109 collaborators; Working Group on Polytrauma of the German Trauma Society with one study, nine authors, and four collaborators; RECORD Trial Group with one study and 14 authors; EURODEM Risk Factors Research Group with one study and 10 authors; AG Polytrauma of the German Trauma Society (DGU) with one study and nine authors; Novoseven Trauma Study Group with one study and eight authors; and National Emergency X-Radiography Utilization Study Group with one study and five authors). In addition, the number of total authors and collaborators was 126 and 124I, respectively, in these study groups (according to Thomson Reuters' WoS Core Collection). Analyses of the publications (between 1980 and 2013) and citation rates in

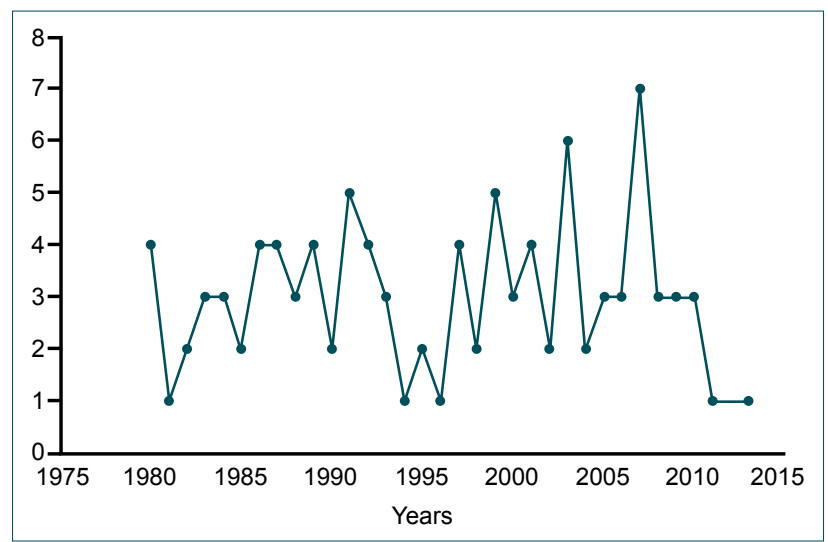

Figure 1. The top 100 cited articles published in each year (19802013). 


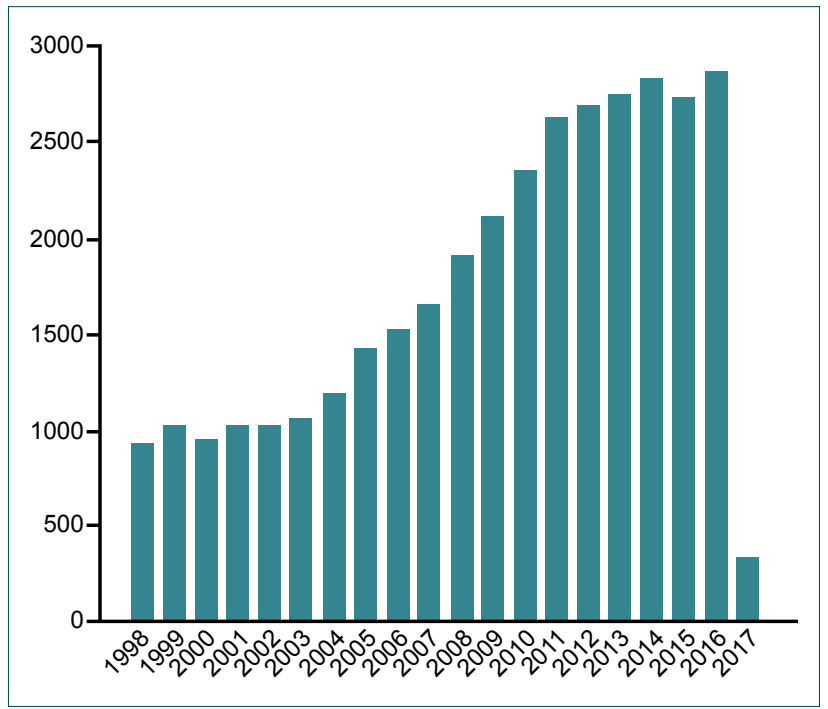

Figure 2. Citations in each year (last 20 years, source: Web of Science database).

each year (between 1998 and 2017) of "key papers" in traumatology found that the highest number of publications was seen in 2007 (seven publications) and the highest number of citations was seen in 2016 (2875 citations) (Figs. I and 2).

\section{Authorship}

The total number of authors of "classic papers" included in our study was 649, and average authorship in the classics in traumatology was 6.49 \pm 5.46 (I-32) (according to Thomson Reuters' WoS Core Collection and PubMed). We analyzed the distribution of 20 authors who were included in more than three articles among the top 100 cited articles and found that the first three ranks were shared by Hoyt DB, Moore EE, and Moore FA, with five articles each. In addition to this, we observed that the most frequent first author of key papers included in our research was Campion HR with four articles, and Hoyt DB, Moore EE, and Copes WJ were detected to be the most frequent co-authors, with four articles each. In addition, Hoyt DB and Moore EE were included as first authors in one article. In addition, we also found that the number of authors included in two articles was 53 (Table I).

\section{Countries and Institutions or Organizations}

The three most common listed countries with two or more publications in the top 100 cited articles were USA (69\%), England (13\%), and Germany (II\%), respectively. In total, 20 countries were listed 155 times in the top 100 cited articles (range: 2-69) (Table 2). In the present study, we determined that the most common listed institution or organization was the University of California (USA), and it was listed 34 times in the top 100 cited articles. Moreover, the number of institutions or organizations that published three or more publications was determined to be $2 \mathrm{I} / 3 \mathrm{I}(67.7 \%)$ of them were in USA (Table 3).

Table I. The most common authors with two or more in the top 100 cited articles

\begin{tabular}{lll}
\hline Author & Affliation & Number \\
\hline Hoyt DB & University of Maryland Medical Center, Baltimore (USA) & 5 \\
Moore EE & Denver Health Medical Center, Colorado (USA) & 5 \\
Moore FA & USAISR, Fort Sam Houston, TX 78234-63I5 (USA) & 5 \\
Bouillon B & RWTH University Hospital Aachen, Aachen (Germany) & 4 \\
Brohi K & University of Maryland Medical Center, Baltimore (USA) & 4 \\
Champion HR & USAISR, Fort Sam Houston, TX 78234-63I5 (USA) & 4 \\
Jurkovich GJ & Johns Hopkins Bloomberg School of Public Health, Baltimore (USA) & 4 \\
Trunkey DD & University of North Carolina, North Carolina (USA) & 4 \\
Copes WS & Washington Hospital Center, Washington DC (USA) & 4 \\
Hunt BJ & RWTH University Hospital Aachen, Aachen (Germany) & 4 \\
Croce MA & University of Tennessee, Memphis (USA) & 3 \\
Fabian TC & University of Tennessee, Memphis (USA) & 3 \\
Hall ED & Parke-Davis Pharmaceutical Research, Michigan (USA) & 3 \\
Holcomb JB & University of Maryland Medical Center, Baltimore (USA) & 3 \\
Lefering R & Ludwig-Maximilians-University, Munich (Germany) & 3 \\
Neugebauer E & RWTH University Hospital Aachen, Aachen (Germany) & 3 \\
Rivara FP & Johns Hopkins Bloomberg School of Public Health, Baltimore (USA) & 3 \\
Rossaint R & RWTH Aachen University Hospital, Aachen, (Germany) & 3 \\
Sacco WJ & Washington Hospital Center, Washington, DC (USA) & 3 \\
Wade CE & United States Army Institute of Surgical Research, Tt Sam Houston (USA) & 3 \\
\hline
\end{tabular}


Table 2. The most common listed countries with two or more in the top 100 cited articles

\begin{tabular}{lc}
\hline Country & Number \\
\hline The United States of America & 69 \\
The United Kingdom & 13 \\
Germany & 11 \\
Canada & 9 \\
Netherlands & 6 \\
France & 5 \\
Scotland & 5 \\
Switzerland & 5 \\
Denmark & 4 \\
Israel & 4 \\
Australia & 3 \\
Austria & 3 \\
Spain & 3 \\
Sweden & 3 \\
Belgium & 3 \\
Czech Republic & 2 \\
Finland & 2 \\
Italy & 2 \\
Japan & 2 \\
Slovenia & 2 \\
\hline
\end{tabular}

"Number of times listed of total 20 countries in the top 100 cited articles.

\section{Funding}

In addition to this, we also detected that 70 of the top 100 cited articles in traumatology, which are considered "topic trends," received funding support from 47 different funding agencies, and it was observed that the funding agencies that supported these scientific studies were NINDS NIH HHS (seven studies), NIGMS NIH HHS (six studies), and PHS HHS (four studies) (according to Thomson Reuters' WoS Core Collection).

\section{Journals and Proceedings Papers}

In the present study, 66 of the top 100 cited articles were published in journals that had an impact factor (IF) of $\geq 2.6$ (range: 2.648-72.406, according to Clarivate Analytics, 2017). In addition, we also found that "The Journal of Trauma and Acute Care Surgery" (previously known as "The Journal of Trauma Injury Infection and Critical Care," which was sponsored from the beginning by the American Association for the Surgery of Trauma; AAST) had the highest number of publications (23 publications; Table 4). Moreover, we observed that the number of proceedings papers among the top 100 articles in 16 national and international scientific activities was 17, and the most presented proceedings paper was at the "56th Annual Meeting of the AAST" (date: September, 19-2I,
Table 3. Institutions of origin with three or more in the top 100 cited articles

\begin{tabular}{|c|c|c|}
\hline Rank & Institution & Number \\
\hline I & University of California, (USA) & 34 \\
\hline 2 & University of Colorado (USA) & 21 \\
\hline 3 & University of Washington (USA) & 12 \\
\hline 4 & University of Toronto (Canada) & 6 \\
\hline 5 & Witten Herdecke University (Germany) & 6 \\
\hline 6 & University of Maryland (USA) & 6 \\
\hline 7 & University of Michigan (USA) & 6 \\
\hline 8 & Harvard University (USA) & 5 \\
\hline \multirow[t]{2}{*}{9} & San Fransisco General Hospital Medical & \\
\hline & Center (USA) & 5 \\
\hline 10 & Boston University (USA) & 4 \\
\hline 11 & Denver Health Medical Center (USA) & 4 \\
\hline 12 & Oregon University (USA) & 4 \\
\hline 13 & Sunnybrook Research Institue (Canada) & 4 \\
\hline 14 & University of Pennsylvania (USA) & 4 \\
\hline 15 & Washington Hospital Center (USA) & 4 \\
\hline 16 & Ludwig Boltzmann Institute (Germany) & 3 \\
\hline 17 & Mayo Clinic (USA) & 3 \\
\hline 18 & Oregon Health \& Science University (USA) & 3 \\
\hline \multirow[t]{2}{*}{19} & Pennsylvania Commonwealth System & \\
\hline & of Higher Education-PCSHE (USA) & 3 \\
\hline 20 & Pfizer Co. (USA) & 3 \\
\hline 21 & Royal London Hospital (England) & 3 \\
\hline 22 & RWTH Aachen University (Germany) & 3 \\
\hline 23 & State University of New York (USA) & 3 \\
\hline 24 & United States Army (USA) & 3 \\
\hline 25 & United States Department of Defense (USA) & 3 \\
\hline 26 & University of Glascow (UK) & 3 \\
\hline \multirow[t]{2}{*}{27} & University of Medicine and Dentistry & \\
\hline & of New Jersey (USA) & 3 \\
\hline 28 & University of Pittsburgh (USA) & 3 \\
\hline 29 & University of Southern California (USA) & 3 \\
\hline 30 & University of Tennessee (USA) & 3 \\
\hline 31 & University Hospital Zurich (Switzerland) & 3 \\
\hline
\end{tabular}

1996; Houston TX, USA) (according to Thomson Reuters' WoS Core Collection).

\section{Main subjects}

The three most common topics among the top 100 cited articles in traumatology were central nervous system (CNS) trauma (2I articles), major trauma-hemorrhage-bleeding control-transfusion-early coagulopathy (I8 articles), and 
Table 4. List of journals in which two or more published articles

\begin{tabular}{lccc}
\hline Rank & Journal & Number of articles & Impact Factor (2016)* $^{*}$ \\
\hline 1 & The Journal of Trauma and Acute Care Surgery & 23 & 2.802 \\
2 & Annals of Surgery & 9 & 8.980 \\
3 & The Lancet & 8 & 47.831 \\
4 & The New England Journal of Medicine & 6 & 72.406 \\
5 & Journal of The American Medical Association & 5 & 44.405 \\
6 & The Journal of Critical Care & 3 & 2.648 \\
7 & Critical Care Medicine & 2 & 7.050 \\
8 & Free Radical Biology \& Medicine & 2 & 5.606 \\
9 & Journal of Neuroscience & 2 & 5.988 \\
10 & Journal of Neurotrauma & 2 & 5.190 \\
11 & Neurology & 2 & 7.592 \\
12 & Science & 2 & 37.205 \\
\hline
\end{tabular}

"2016 Journal Citation Reports ${ }^{\circledast}$ (Clarivate Analytics, 2017).

trauma care-trauma care systems (eight articles), respectively (Table 5).

\section{Study Types and Levels of Evidence}

In addition, among the top 100 "classic papers" in traumatology, the most preferred study type among researchers was clinical studies (92 articles) and the most preferred sub-type was prospective comparative studies (27 articles). In our study, the mean level of evidence was found to be $2.45 \pm 1.05$ (I-4). In addition, evidence group of 54 articles were (prospective/retrospective comparative studies, retrospective cohort studies, case-control studies, descriptive studies, cross-sectional studies, and validation studies), and evidence group of 26 articles was A (meta-analysis of RCT, systematic review, RCT, and prospective cohort study). Lastly, the level of evidence of 20 articles were $C$ group (reviews, expert committee reports, and expert opinions) (Table 6).

\section{DISCUSSION}

Trauma or injury with its beforemath and aftermath is a complex series of events that include victims. In recent years, new concepts that prioritize cost-effectiveness, such as damage control resuscitation and damage control surgery, are increasingly becoming widespread. ${ }^{[13,14]}$ Trauma has different types of etiologies and pathophysiological mechanisms based on its type. ${ }^{[15,16]}$ Moreover, acoustic trauma should not be forgotten. However, very few bibliometric studies have been conducted in the field of traumatology. Thus, we prioritized conducting a study on this subject.

We preferred to conduct such a bibliometric study for the beginning in the field of traumatology. Although frequently criticized, particularly in terms of its statistical results, bibliometric citation analyses provide important clues about the current best-cited or landmark articles to researchers because it reflects scientific improvements in the respective field and landmark papers and topic trends in a chronological perspective and in a systematic manner. ${ }^{[8,17,18]}$ In the last 30 years, many bibliometric article analyses have been conducted in the field of clinical medicine. ${ }^{[19-2 \mid]}$ Scientometric analyses, which include altmetric scores at different publication levels or values, have also been added to these studies in recent years. ${ }^{[22]}$

We utilized current medical databases, primarily the WoS database and PubMed, in our bibliometric analysis. Despite the fact that many international medical databases (including PubMed, ScienceDirect, Medline, Scopus, Embase, EBSCO Host, etc.) have been used in citation analysis studies, the most frequently used source is Thomson Reuters' WoS Core Collection. The WoS database includes important information in terms of detecting citations and researching other relevant academic effects. ${ }^{[23]}$ Thus, to conduct this bibliometric study on the 100 most influential manuscripts, as in many similar types of researches.

It is also evident that the citation rates of articles are high and the citation range has a narrow distribution in this bibliometric study. This may be because studies conducted on attractive subjects of traumatology, such as evaluating trauma care, which has multiple effects and results, are high in number and also that produced articles are published in journals with high IFs; therefore, there are many citations. A scientific article being cited frequently and being published in journals with high IFs might be a significant indicator of its quality. In addition to this, there are many factors apart from the number of citations. ${ }^{[24]}$ Being the first and original article in the respective field, which provides insight to researchers working in that field, is only of these other factors. ${ }^{[25]}$ In a research 
Table 5. The most common topics among the top 100 cited articles

\begin{tabular}{ll}
\hline Topic & Number \\
\hline
\end{tabular}

Central nervous system trauma

Major trauma-hemorrhage-bleeding control-

transfusion-early coagulopathy

Trauma care

Major trauma-infection-sepsis

Abdominal trauma-feeding-septic mortality-

gut bacterial translocation-decontamination

Fracture-dislocation-extremity trauma-hand

wrist cumulative trauma disorder

Trauma score

Spinal cord trauma

Acoustic trauma

Trauma-venous thromboembolism

Traumatic deaths

Severe blunt trauma-ARDS-hemorrhagic

shock-cytokine patterns

Trauma-postoperative fibrinolytic shutdown

Abdominal trauma-abdominal compartment syndrome

Abdominal trauma-staged laparotomy

Hepatic blunt trauma management

Major trauma-parachute use

Torture-trauma-posttraumatic stress disorder

Vascular trauma-endothelial precursors

Major trauma-plasma fibronectin (opsonic

glycoprotein) levels

Trauma-surgery-the stress response

Multiple trauma-sedation-mortality

Trauma-whole body CT-survivre

Trauma-rheumatoid arthritis-matrix

metalloproteinases

Obstetric trauma-vaginal delivery

Blunt aortic injury

Accidental and intentional injuries

Trauma-orthopedic-spinal implants-PEEK

biomaterials

Trauma hypothermia

Trauma-inflammation-microbes-thymic stromal

lymphopoietin

on 5-year citation reports of cardiovascular articles, Ranasinghe 1 et al. ${ }^{[26]}$ stated that few citations might be due to many factors, including article and publication period. However, the fact that many have cited an article does not necessarily indicate a high level of evidence, and a positive correlation between productivity in terms of scientific activity and high citation is also not necessary. ${ }^{[27]}$ Some authors have even suggested scientist' IF and metric evaluation scores in addition to the $\mathrm{H}$-index, total IF, and citation number for evaluating a researcher's scientific activity. ${ }^{[28]}$

Factors such as the number of citations being in favor of old journals and publications, scientific articles not cited within I-2 years after their publication, and post-publication citation peak being between 3 and 10 years and articles losing their importance after that period are the main limitations in determining the value of articles in citation classics studies. [8,25] This effect was only partially displayed in our bibliometric research because researches cited in 2016, in which the number of citations peaked, were published 5-15 years ago.

The highest cited article and the second most common type of article being review studies in this bibliometric research is a typical example of that assumption. In his study, Garfield $E^{[17]}$ underlined that most of the highly cited articles were review studies.

Articles analyzed in our bibliometric study had a relatively higher average authorship rate $[6.83 \pm 5.49(\mathrm{I}-32)]$ because the level of evidence was predominantly $A$ and $B$ groups (80\%). Moreover, there were fewer observational studies, and most of these studies were extensive, while some of them were multi-centered. Furthermore, author groups were conducted with collaborators. A study by Tilak $G$ et al. ${ }^{[29]}$ on authorship increments in scientific researches revealed that the number of observational studies decreased in three major international journals between 1960 and 2010, whereas there was a significant increase in single- and multi-center RCTs; however, the rate of author per article increased more than three times for observational studies (2.6 to 10.1). In this context, the results of our study are partially compatible with the results of the research conducted by Tilak $G$ et al. particularly in terms of the increment reported in observational researches.

According to our research data, among the 100 most influential manuscripts in traumatology both in terms of the number of authors who were included in more than one article and the number of presented proceedings papers and scientific activities, USA is at the forefront. ${ }^{[23,30]}$

The publication language of all classics papers included in our citation analysis research was English. The official language of the country of origin of publications is an important factor for the selection of language for articles. Although different languages were used, most of the articles in the recent medicine literature were in English. ${ }^{[31]}$

We have underlined in our bibliometric study that institutions or organizations located in USA are more prominent both in terms of the number of institutions producing publications and in terms of the number of publications per institution. USA has 
Table 6. Study design and levels of evidence by SIGN of the top 100 cited articles

\begin{tabular}{lccc}
\hline Study type and sub-type & Level of evidence & Group & Number \\
\hline Clinical research & & & \\
Meta-analysis of RCT & I & A & 2 \\
Systematic review & I & A & 4 \\
Randomized controlled trial & I & A & I4 \\
Prospective cohort study & I & A & 6 \\
Prospective comparative study (clinical) & 2 & B & I8 \\
Retrospective comparative study (clinical) & 3 & B & 3 \\
Retrospective cohort study & 3 & B & II \\
Case-control study & 3 & B & 6 \\
Observational-descriptive study & 3 & B & 2 \\
Cross-sectional-correlation study & B & 4 \\
Validation study & 3 & B & I \\
Review & 3 & C & I5 \\
Expert committee report & 4 & C & 2 \\
Expert opinion (editorial, letter, and note) & 4 & C & 3 \\
Experimental animal study & 4 & & 9 \\
Prospective comparative study & & B & \\
\hline SIGN: Scottish Intercollegiate Guidelines Network; RCT: Randomized control trial. & &
\end{tabular}

the highest production of scientific publications, including in medicine and other health science fields. USA has the highest number of scientific publications in many fields. ${ }^{[23,30,31]}$

The result of our bibliometric study, which displays that most of the $70 \%$ of the 100 most influential manuscripts are being supported by funding agencies in USA and the EU, is a solid indicator of this hypothesis. Although the amount of allowance has reduced in recent years, educational and scientific studies are generally supported with funding at a greater extent in developed countries relative to developing countries. ${ }^{[32,33]}$

A high IF is an important scientometric criterion that demonstrates the quality of a journal. ${ }^{[34]}$ As in our research, most of the top 100 cited articles in traumatology were included in journals with an IF of $\geq 2.6$, which is an important indicator that displays that key papers pertaining to trauma are preferred by journals with higher IFs.

The most common topic in our study was CNS trauma. Traumatic brain injury (TBI) is a particularly important problem with socioeconomical and medical consequences among the young population in terms of its result. ${ }^{[35]}$ Abusive head trauma is a typical example of this. ${ }^{[36]}$ According to geographical regions, various incidences have been reported on the epidemiology of TBI. ${ }^{[37,38]}$ Nguyen $\mathrm{R}$ et al. ${ }^{[39]}$ conducted a systematic review and meta-analysis regarding this phenomenon; according to this, the international cumulative incidence rate of the TBI among all age groups is reported to be 295 of 100.000 people. The pooled annual incidence proportion for all ages was 295 per 100,000 (95\% confidence interval: 274-317), and the international cumulative annual incidence speed is reported to be 349 of 100.000 people among all age groups. In light of this important information obtained from these studies, we conclude that CNS trauma is important among the fields of traumatology.

These were the second and third most common topics of our bibliometric study, and both of these trauma research subjects are based on the cost effectivity increasing concerns on traumatology. During the last few years, the correlation between trauma and bleeding and control of the bleeding earned an importance in the field of trauma research. Therefore, Damage Control Resuscitation and Damage Control Surgery concepts, which are related to trauma resuscitation can be seen as a typical reflection of this. ${ }^{[8,9]}$ Again, in the last few years, trauma care and trauma care systems can be stated as other important trending traumatology subjects. ${ }^{[40]}$

\section{Strengths}

The strength of this study is the provision of a quick and direct reach to determine topic trends and up-to-date information regarding traumatology with no requirements of any advanced analysis or statistical methods.

\section{Limitations}

Only the total number of citations (excluding self-citations) 
and the total number of self-citations are presented in this study, and no article-based self-citation analyses was performed, which is a limitation of this study. In addition, conducting bibliometric analyses based on citations is a subjective constraint to prove the quality of research and to determine the number of publications by year as well as to evaluate authors' scientific efficiency.

\section{Future Directions}

Occasional bibliometric analyses for different medical disciplines and sub-specialties demonstrate the improvements in that field from a nominative perspective, in contrast with advanced research methods. The data of current studies may provide cost effectivity in planning and funding of future research projects. Bibliometric studies are relatively subjective initial and basic researches in terms of scientific value. In the last decade, altmetric studies including multiple evaluations of classical articles were preferred as they are scientifically more objective.

\section{Conclusion}

Traumatology is an important surgical medicine discipline that is the subject of many topic trend researches. Despite its flaws, bibliometric citation analyses in traumatology, as in many scientific fields, enables the systematic identification of true landmark publications and the distribution of citations of these publications by years, main topics, institutions of influential papers, published scientific journals, research types and subtypes, and level of evidence, thus resulting in great academic contribution to traumatology.

Financial disclosure: The authors declare no financial support.

Conflict of interest: None declared.

\section{REFERENCES}

1. Miniño AM. Death in the United States, 2011. NCHS Data Brief 2013:1-8.

2. World Health Organization. The global burden of disease: 2004 update. Geneva: WHO, 2004. Available at: http://www.who.int/healthinfo/ global_burden_disease/GBD_report_2004update_full.pdf, Accessed Apr 20, 2018.

3. Mechem CC. Emergency Medical Services. In: Tinnialli JE, Stapczynski JS, Ma JO, Cline DM, Cydulka RK, Meckler GD, editors. Tintinalli's Emergency Medicine: A Comprehensive Study Guide. 7th ed. New York: McGraw-Hill; 2011. p. 1-15.

4. Tugrul S. Cerrahi hastalarda yoğun bakım. In: Ertekin C, Guloglu R, Taviloglu K, editors. Acil Cerrahi. 1st ed. (Turkish) Istanbul: Nobel Tip Yayınc1lik; 2009. p. 37-48.

5. Campbell WB, Lee EJ, Van de Sijpe K, Gooding J, Cooper MJ. A 25year study of emergency surgical admissions. Ann R Coll Surg Engl 2002;84:273-7. [CrossRef]

6. Sauaia A, Moore FA, Moore EE, Moser KS, Brennan R, Read RA, et al. Epidemiology of trauma deaths: a reassessment. J Trauma 1995;38:18593. [CrossRef]
7. Soybir GR.Travma epidemiyolojisi. In: Ertekin C, Taviloğlu K, Guloğlu R, Kurtoğlu M, Belgrden S. Travma. 1st ed. Istanbul: İstanbul Medikal Yayıncilik; 2005. p. 26-32.

8. Gehanno JF, Takahashi K, Darmoni S, Weber J. Citation classics in occupational medicine journals. Scand J Work Environ Health 2007;33:24551. [CrossRef]

9. Ellul T, Bullock N, Abdelrahman T, Powell AG, Witherspoon J, Lewis WG. The 100 most cited manuscripts in emergency abdominal surgery: A bibliometric analysis. Int J Surg 2017;37:29-35. [CrossRef]

10. Sharma B, Lawrence DW. Top-cited articles in traumatic brain injury. Front Hum Neurosci 2014;8:879. [CrossRef]

11. Held M, Engelmann E, Dunn R, Ahmad SS, Laubscher M, Keel MJB, et al. Gunshot induced injuries in orthopaedic trauma research. A bibliometric analysis of the most influential literature. Orthop Traumatol Surg Res 2017;103:801-7. [CrossRef]

12. Zeng XT, Li S, Gong K, Guo ZZ, Liu TZ, He DL, et al. Evidence-based evaluation of recent clinical practice guidelines for the diagnosis and treatment of benign prostatic hyperplasia [Article in Chinese]. Zhonghua Yi Xue Za Zhi 2017;97:1683-7.

13. Holcomb JB, Jenkins D, Rhee P, Johannigman J, Mahoney P, Mehta S, et al. Damage control resuscitation: directly addressing the early coagulopathy of trauma. J Trauma 2007;62:307-10. [CrossRef]

14. Gupta A, Kumar S, Sagar S, Sharma P, Mishra B, Singhal M,et al. Damage control surgery: 6 years of experience at a level I trauma center. Ulus Travma Acil Cerrahi Derg 2017;23:322-7.

15. Kayahan C,Uzar AI. Travma kinematiği. In: Ertekin C, Taviloglu K, Guloglu R,editors. Travma. 1st ed. Istanbul: İstanbul Medikal Yayıncilk; 2005. p. 33-45.

16. Banakis Hartl RM, Mattingly JK, Greene NT, Farrell NF, Gubbels SP, Tollin DJ. Drill-induced Cochlear Injury During Otologic Surgery: Intracochlear Pressure Evidence of Acoustic Trauma. Otol Neurotol 2017;38:938-47. [CrossRef]

17. Garfield E. 100 citation classics from the Journal of the American Medical Association. JAMA 1987;257:52-9. [CrossRef]

18. Thomas K, Moore CM, Gerharz EW, O'Brien T, Emberton M.. Classic Papers in Urology. European Urology 2003;43:591-5. [CrossRef]

19. Elgafy HK, Miller JD, Hashmi S, Ericksen S. Top 20 cited Spine Journal articles, 1990-2009. World J Orthop 2014;5:392-7. [CrossRef]

20. Joyce KM, Joyce CW, Kelly JC, et al. Levels of Evidence in the Plastic Surgery Literature: A Citation Analysis of the Top 50 'Classic' Papers. Arch Plast Surg 2015;42:411-8. [CrossRef]

21. Matthews AH, Abdelrahman T, Powell AG, Lewis WG. Surgical Education's 100 Most Cited Articles: A Bibliometric Analysis. J Surg Educ 2016;73:919-29. [CrossRef]

22. Trueger NS, Thoma B, Hsu CH, Sullivan D, Peters L, Lin M. The Altmetric Score: A New Measure for Article-Level Dissemination and Impact. Ann Emerg Med 2015;66:549-53. [CrossRef]

23. Leydesdorff L, Carley S, Rafols I. Global maps of science based on the new Web-of-Science categories. Scientometrics 2013;94:589-3. [CrossRef]

24. Fu HZ, Wang MH, Ho YS. The most frequently cited adsorption research articles in the Science Citation Index (Expanded). J Colloid Interface Sci 2012;379:148-56. [CrossRef]

25. Park KM, Kim JE, Kim Y, Kim SE, Yoon DY, Bae JS. Searching the Footprints of Pioneers on Neurology: A Bibliometric Analysis. Eur Neurol 2017;77:152-61. [CrossRef]

26. Ranasinghe I, Shojaee A, Bikdeli B, Gupta A, Chen R, Ross JS, et al. Poorly cited articles in peer-reviewed cardiovascular journals from 1997 to 2007: analysis of 5-year citation rates. Circulation 2015;131:1755-62.

27. Abramo G, Cicero T, D'Angelo CA. Are the authors of highly-cited ar- 
ticles also the most productive ones? Journal of Informetrics 2014;8:8997. [CrossRef]

28. Lippi G, Mattiuzzi C. Scientist impact factor (SIF): a new metric for improving scientists' evaluation? Ann Transl Med 2017;5:303. [CrossRef]

29. Tilak G, Prasad V, Jena AB. Authorship Inflation in Medical Publications. Inquiry 2015;52. pii: 0046958015598311. [CrossRef]

30. Paris G, De Leo G, Menozzi P, Gatto M. Region-based citation bias in science. Nature 1998;396:210. [CrossRef]

31. Diekhoff T, Schlattmann P, Dewey M. Impact of article language in multi-language medical journals-a bibliometric analysis of self-citations and impact factor. PLoS One 2013;8:e76816. [CrossRef]

32. Weinberg BA, Owen-Smith J, Rosen RF, Schwarz L, Allen BM, Weiss $\mathrm{RE}$, et al. Research funding. Science funding and short-term economic activity. Science 2014;344:41-3. [CrossRef]

33. Abbott A. Europe's next big science-funding programme urged to double its budget. Nature 2017;547:17. [CrossRef]

34. Nielsen MB, Seitz K. Impact Factors and Prediction of Popular Topics in a Journal. Ultraschall Med 2016;37:343-5. [CrossRef]
35. Kuppermann N, Holmes JF, Dayan PS, Hoyle JD Jr, Atabaki SM, Holubkov R, et al; Pediatric Emergency Care Applied Research Network (PECARN). Identification of children at very low risk of clinicallyimportant brain injuries after head trauma: a prospective cohort study. Lancet 2009;374:1160-70. [CrossRef]

36. Jenny C, Hymel KP, Ritzen A, Reinert SE, Hay TC. Analysis of missed cases of abusive head trauma. JAMA 1999;281:621-6. [CrossRef]

37. Peeters W, van den Brande R, Polinder S, Brazinova A, Steyerberg EW, Lingsma HF, et al. Epidemiology of traumatic brain injury in Europe. Acta Neurochir (Wien) 2015;157:1683-96. [CrossRef]

38. El-Menyar A, Mekkodathil A, Al-Thani H, Consunji R, Latifi R. Incidence, Demographics, and Outcome of Traumatic Brain Injury in The Middle East: A Systematic Review. World Neurosurg 2017:6-21.

39. Nguyen R, Fiest KM, McChesney J, Kwon CS, Jette N, Frolkis AD, et al. The International Incidence of Traumatic Brain Injury: A Systematic Review and Meta-Analysis. Can J Neurol Sci 2016;43:774-85. [CrossRef]

40. Cales RH, Trunkey DD. Preventable trauma deaths. A review of trauma care systems development. JAMA 1985;254:1059-63. [CrossRef]

\section{ORIJINAL ÇALIŞMA - ÖZET}

\section{Travmatolojide en sık alıntılanan 100 makale: Bibliyometrik bir analiz}

\section{Dr. Mehmet Dokur, ${ }^{1}$ Dr. Erdal Uysal ${ }^{2}$}

${ }^{1}$ Biruni Üniversitesi Tıp Fakültesi, Acil Tıp Anabilim Dalı, İstanbul

${ }^{2}$ Sanko Üniversitesi Tıp Fakültesi, Genel Cerrahi Anabilim Dalı, Gaziantep

AMAÇ: Bu bibliyometrik çalışmada, travmatoloji alanındaki en sık alıntılanan 100 makalenin çok yönlü analizini yapmayı amaçladık.

GEREÇ VE YÖNTEM: Biz bu çalışmada, Web of Science ve PubMed'teki veri tabanlarından elde ettiğimiz, 1975 ile 2017 yılları arasında yayınlanmış 56.980 travma makalesi içinden en çok alıntılanan ilk 100 'ünü alıntılanma sayılarına ve yayın yıllarına, köken aldığı ülkelere ve kurum veya organizasyonlarına, en sık tercih edilen konularına, fonlanma durumlarına, makale tiplerine ve kanıt düzeylerine göre analiz ettik.

BULGULAR: Travmatoloji alanında en sık alıntılanan 100 makaledeki toplam yazar sayısını 649 ve yazar sayısı ortalamasını $6.49 \pm 5.46$ (dağıım: I-32), toplam çalışma grubu sayısını 8 ve eşlik eden çalışmacı sayısını ise 124I olarak saptadık. Amerika Birleşik Devletleri, yayınlarda en sık yer alan ülke ve kurum ya da organizasyon olma ve bilimsel aktivitede sunulan makale sayısı bakımlarından ilk sırada idi. En çok alıntılanan 100 makalenin 70'inin, gelişmiş ülkelerdeki fon desteği veren kuruluşlar tarafından desteklendiğini belirledik. Travmatoloji ile ilgili en çok alıntılanan 100 makalede en sık tercih edilen ilk üç konu başlğını santral sinir sistemi travması (2l makale), majör travma-kanama-kanama kontrolü-transfüzyon-erken koagülopati ( 18 makale) ve travma bakımı ve sistemleri (8 makale) olarak saptadık. En sık alıntılanan 100 travmatoloji makalesinin kanıt ortalaması $2.45 \pm 1.05$ (dağılım: I-4) idi. Ayrıca biz en çok alıntılanan 100 makalenin 66'sının etki faktörü 2.6 daha yüksek olan bilimsel dergilerde (dağıım: 2.648-72.406) yayınlandığını belirledik. Araştırmacılar tarafından en sık tercih edilen çalışma tipinin klinik araştırma (92 makale) ve çalışma alt tipinin ise karşılaştırmalı ileriye yönelik çalışmalar (27 makale) olduğunu saptadık. Travmatolojideki klasik makalelerin kanıt gruplarının dağılımlarını ise sırasıyla B (54 makale), A (26 makale) ve C (20 makale) olarak belirledik.

TARTIŞMA: Makalelerin bilimsel değerini saptamadaki bazı eksikliklerine rağmen travmatoloji alanındaki klasik makalelerin alıntılanma analizleri, önemli akademik katkılar sağlayabilir.

Anahtar sözcükler: Bibliyometrik; makaleler; travmatoloji; yüksek sayıda alıntılanma.

Ulus Travma Acil Cerrahi Derg 20 18;24(4):294-302 doi: 10.5505/tjtes.2017.74857 
Appendix I. The top 100 cited articles in traumatology

Rank Article Times cited

I. Boyd CR, Tolson MA, Copes WS. Evaluating trauma care: the TRISS method. Trauma Score and the Injury Severity Score. J Trauma 1987;27:370-8.

2. Sauaia A, Moore FA, Moore EE, Moser KS, Brennan R, Read RA, et al. Epidemiology of trauma deaths: a reassessment. J Trauma 1995;38:185-93.

3. Champion HR, Sacco WJ, Copes WS, Gann DS, Gennarelli TA, Flanagan ME. A revision of the Trauma Score. J Trauma 1989;29:623-9.

4. MacKenzie EJ, Rivara FP, Jurkovich GJ, Nathens AB, Frey KP, Egleston BL, et al. A national evaluation of the effect of trauma-center care on mortality. N Engl J Med 2006;354:366-78.

5. Tator $\mathrm{CH}$, Fehlings MG. Review of the secondary injury theory of acute spinal cord trauma with emphasis on vascular mechanisms. J Neurosurg 1991;75:15-26.

6. Kudsk KA, Croce MA, Fabian TC, Minard G, Tolley EA, Poret HA, et al. Enteral versus parenteral feeding. Effects on septic morbidity after blunt and penetrating abdominal trauma. Ann Surg 1992;215:503-II.

7. CRASH-2 trial collaborators (570 researchers), Shakur H, Roberts I, Bautista R, Caballero J, Coats T,

Dewan $Y$, et al. Effects of tranexamic acid on death, vascular occlusive events, and blood transfusion in traumapatients with significant haemorrhage (CRASH-2): a randomised, placebo-controlled trial. Lancet 2010;376:23-32.

8. Champion HR, Copes WS, Sacco WJ, Lawnick MM, Keast SL, Bain LW Jr, et al. The Major Trauma Outcome Study: establishing national norms for trauma care. J Trauma 1990;30:1356-65.

9. Geerts WH, Code KI, Jay RM, Chen E, Szalai JP. A prospective study of venous thromboembolism after major trauma. N Engl J Med 1994;33I:I60I-6.

10. Rappaport M, Hall KM, Hopkins K, Belleza T, Cope DN. Disability rating scale for severe head trauma: coma to community. Arch Phys Med Rehabil 1982;63:1 18-23.

II. Marsh JL, Slongo TF, Agel J, Broderick JS, Creevey W, DeCoster TA, et al. Fracture and dislocation classification compendium - 2007: Orthopaedic Trauma Associationclassification, database and outcomes committee. J Orthop Trauma 2007;2I(I0 Suppl):SI-I33.

12. Mollica RF, Caspi-Yavin Y, Bollini P, Truong T, Tor S, Lavelle J. The Harvard Trauma Questionnaire.

Validating a cross-cultural instrument for measuring torture, trauma, and posttraumatic stress disorder in Indochinese refugees. J Nerv Ment Dis 1992;180: I I I-6.

13. Champion HR, Sacco WJ, Carnazzo AJ, Copes W, Fouty WJ. Trauma score. Crit Care Med 198I;9:672-6.

14. Gill M, Dias S, Hattori K, Rivera ML, Hicklin D, Witte L,et al.Vascular trauma induces rapid but transient mobilization of VEGFR2(+)ACI33(+) endothelialprecursor cells. Circ Res 200I;2-88:167-74.

15. Saba TM, Jaffe E. Plasma fibronectin (opsonic glycoprotein): its synthesis by vascular endothelial cells and role in cardiopulmonary integrity after trauma as related to reticuloendothelial function. Am J Med 1980;68:577-94.

16. Braughler JM, Hall ED. Central nervous system trauma and stroke. I. Biochemical considerations for oxygen radicalformation and lipid peroxidation. Free Radic Biol Med. 1989;6:289-30I.

17. Godina M. Early microsurgical reconstruction of complex trauma of the extremities. Plast Reconstr Surg 1986;78:285-92.

18. Moore FA, Moore EE, Jones TN, McCroskey BL, Peterson VM. TEN versus TPN following major abdominal trauma-reduced septic morbidity. J Trauma 1989;29:916-22.

19. Desborough JP. The stress response to trauma and surgery. Br J Anaesth 2000;85:109-17.

20. Ochoa JB, Udekwu AO, Billiar TR, Curran RD, Cerra FB, Simmons RL, et al. Nitrogen oxide levels in patients after trauma and during sepsis. Ann Surg 1991;214:621-6.

21. MacLeod JB, Lynn M, McKenney MG, Cohn SM, Murtha M. Early coagulopathy predicts mortality in trauma. J Trauma 2003;55:39-44. 
Appendix I. The top 100 cited articles in traumatology (continuation)

\section{Rank Article}

22. Holcomb JB, Jenkins D, Rhee P,Johannigman J, Mahoney P, Mehta S,et al.Damage control resuscitation: directly addressing the early coagulopathy of trauma.J Trauma 2007;62:307-10.

23. Hall ED, Braughler JM. Central nervous system trauma and stroke. II. Physiological and pharmacologica evidence for involvement of oxygen radicals and lipid peroxidation. Free Radic Biol Med 1989;6:303-13.

24. Corwin JT, Cotanche DA. Regeneration of sensory hair cells after acoustic trauma. Science 1988;240:1772-4.

25. Holcomb JB, Wade CE, Michalek JE, Chisholm GB, Zarzabal LA, Schreiber MA, et al. Increased plasma and platelet to red blood cell ratios improves outcome in 466 massively transfused civilian trauma patients. Ann Surg 2008;248:447-58.

26. Hoffman JR, Mower WR, Wolfson AB, Todd KH, Zucker MI. Validity of a set of clinical criteria to rule out injury to the cervical spine in patients with blunt trauma. National Emergency X-Radiography Utilization Study Group. N Engl J Med 2000;343:94-9.

27. Payne JA, Rivera C, Voipio J, Kaila K. Cation-chloride co-transporters in neuronal communication, development and trauma. Trends Neurosci 2003;26:199-206.

28. Grant AM, Avenell A, Campbell MK, McDonald AM, MacLennan GS, McPherson GC, et al. Oral vitamin D3 and calcium for secondary prevention of low-trauma fractures in elderly people (Randomised Evaluation of Calcium Or vitamin D, RECORD): a randomised placebo-controlled trial. Lancet 2005;365:162I-8.

29. Roumen RM, Hendriks T, van der Ven-Jongekrijg J, Nieuwenhuijzen GA, Sauerwein RW, van der Meer JW, et al. Cytokine patterns in patients after major vascular surgery,hemorrhagic shock, and severe blunttrauma.

Relation with subsequent adult respiratory distress syndrome and multiple organ failure.

Ann Surg 1993;218:769-76.

30. Kurtz SM, Devine JN. PEEK biomaterials in trauma, orthopedic, and spinal implants. Biomaterials 2007;28:4845-69.

31. Ryals BM, Rubel EW. Hair cell regeneration after acoustic trauma in adult Coturnix quail. Science 1988;240:1774-6.

32. Suter PM, Suter S, Girardin E, Roux-Lombard P, Grau GE, Dayer JM. High bronchoalveolar levels of tumor necrosis factor and its inhibitors, interleukin-I, interferon, and elastase, in patients with adult respiratory distress syndrome after trauma, shock, or sepsis. Am Rev Respir Dis 1992;145:1016-22.

33. Bliuc D, Nguyen ND, Milch VE, Nguyen TV, Eisman JA, Center JR. Mortality risk associated with low-trauma osteoporotic fracture and subsequent fracture in men and women. JAMA 2009;30I:5 I3-2I.

34. Gentilello LM, Rivara FP, Donovan DM, Jurkovich GJ, Daranciang E, Dunn CW, et al. Alcohol interventions in a trauma center as a means of reducing the risk of injury recurrence. Ann Surg 1999;230:473-80.

35. Smith GC, Pell JP. Parachute use to prevent death and major trauma related to gravitational challenge: systematic review of randomised controlled trials. BMJ 2003;327:1459-6I.

36. Boffard KD, Riou B, Warren B, Choong PI, Rizoli S, Rossaint R, et al; NovoSeven Trauma Study Group.

Recombinant factor VIla as adjunctive therapy for bleeding control in severely injured traumapatients: two parallel randomized, placebo-controlled, double-blind clinical trials. J Trauma 2005;59:8-15.

37. Stoutenbeek CP, van Saene HK, Miranda DR, Zandstra DF. The effect of selective decontamination of the digestive tract on colonisation and infection rate in multiple trauma patients. Intensive Care Med 1984;10:185-92.

38. Lowenstein DH, Thomas MJ, Smith DH, McIntosh TK. Selective vulnerability of dentate hilar neurons following traumatic brain injury: a potentialmechanistic link between head trauma and disorders of the hippocampus. J Neurosci 1992;12:4846-53.

39. Geerts WH, Jay RM, Code KI, Chen E, Szalai JP, Saibil EA, et al. A comparison of low-dose heparin with low-molecular-weight heparin as prophylaxis against venous thromboembolism after major trauma. N Engl J Med 1996;335:70I-7. 
Appendix I. The top 100 cited articles in traumatology (continuation)

40. Stiell IG, Wells GA, Vandemheen KL, Clement CM, Lesiuk H, De Maio VJ, et al. The Canadian C-spine rule for radiography in alert and stable trauma patients. JAMA 200I;286:184I-8.

41. Trunkey DD. Trauma.Trauma. Accidental and intentional injuries account for more years of life lost in the U.S. than cancer and heart disease. Among the prescribed remedies are improved preventive efforts, speedier surgery and further research. Sci Am 1983; 249:28-35.

42. Jenny C, Hymel KP, Ritzen A, Reinert SE, Hay TC. Analysis of missed cases of abusive head trauma. JAMA 1999;281:621-6.

43. Baker CC, Oppenheimer L, Stephens B, Lewis FR, Trunkey DD. Epidemiology of trauma deaths. Am J Surg 1980;140:144-50

44. Thomsen IV. Late outcome of very severe blunt head trauma: a I0-I5 year second follow-up. J Neurol Neurosurg Psychiatry 1984;47:260-8.

45. Clowes GH Jr, George BC, Villee CA Jr, Saravis CA. Muscle proteolysis induced by a circulating peptide in patients with sepsis or trauma. N Engl J Med 1983;308:545-52.

46. Silverstein BA, Fine LJ, Armstrong TJ. Hand wrist cumulative trauma disorders in industry. $\mathrm{Br}$ J Ind Med 1986;43:779-84.

47. Houdijk AP, Rijnsburger ER, Jansen J, Wesdorp RI, Weiss JK, McCamish MA, et al. Randomised trial of glutamineenriched enteral nutrition on infectiousmorbidity in patients with multiple trauma. Lancet 1998;352:772-6.

48. Hess JR, Brohi K, Dutton RP, Hauser CJ, Holcomb JB, Kluger Y,et al.The coagulopathy of trauma: a review of mechanisms. J Trauma 2008;65:748-54.

49. Kuppermann N, Holmes JF, Dayan PS, Hoyle JD Jr, Atabaki SM, Holubkov R, et al; Pediatric Emergency Care Applied Research Network (PECARN). Identification of children at very low risk of clinically-important brain injuries after head trauma: a prospective cohort study. Lancet 2009;374:1 160-70.

50. Fabian TC, Richardson JD, Croce MA, Smith JS Jr, Rodman G Jr, Kearney PA, et al. Prospective study of blunt aortic injury: Multicenter Trial of the American Association for the Surgery of Trauma. J Trauma 1997;42:374-80.

5I. Roof RL, Hall ED. Gender differences in acute CNS trauma and stroke: neuroprotective effects of estrogen and progesterone. J Neurotrauma 2000; 17:367-88.

52. Kauvar DS, Lefering R, Wade CE. Impact of hemorrhage on trauma outcome: an overview of epidemiology, clinical presentations, and therapeutic considerations. J Trauma 2006;60(6 Suppl):S3-II.

53. Malone DL, Dunne J, Tracy JK, Putnam AT, Scalea TM, Napolitano LM. Blood transfusion, independent of shock severity, is associated with worse outcome in trauma. J Trauma 2003;54:898-905.

54. Moore EE, Jones TN. Benefits of immediate jejunostomy feeding after major abdominal trauma-a prospective, randomized study. J Trauma 1986;26:874-8I.

55. Fitch MT, Doller C, Combs CK, Landreth GE, Silver J. Cellular and molecular mechanisms of glial scarring and progressivecavitation: in vivo and in vitro analysis of inflammation-induced secondary injury after CNS trauma. J Neurosci 1999;19:8182-98.

56. Rush BF Jr, Sori AJ, Murphy TF, Smith S, Flanagan JJ Jr, Machiedo GW. Endotoxemia and bacteremia during hemorrhagic shock. The link between trauma and sepsis? Ann Surg 1988;207:549-54.

57. Annegers JF, Grabow JD, Groover RV, Laws ER Jr, Elveback LR, Kurland LT. Seizures after head trauma: a population study. Neurology 1980;30:683-9.

58. Moore FA, Moore EE, Poggetti R, McAnena OJ, Peterson VM, Abernathy CM, et al. Gut bacterial translocation via the portal vein: a clinical perspective with major torso trauma. J Trauma 1991;31:629-36.

59. Unterberg AW, Stover J, Kress B, Kiening KL. Edema and brain trauma. Neuroscience 2004;129:1021-9. of survival. J Trauma 1987;27:1019-24. 
Appendix I. The top 100 cited articles in traumatology (continuation)

\section{Rank Article}

Times cited

61. Uzzan B, Cohen R, Nicolas P, Cucherat M, Perret GY. Procalcitonin as a diagnostic test for sepsis in critically ill adults and after surgery or trauma: a systematic review and meta-analysis. Crit Care Med 2006;34:1996-2003.

62. Allakhverdi Z, Comeau MR, Jessup HK, Yoon BR, Brewer A, Chartier S,et al. Thymic stromal lymphopoietin is released by human epithelial cells in response to microbes, trauma, or inflammation and potently activates mast cells. J Exp Med 2007;204:253-8.

63. Roberts GW, Gentleman SM, Lynch A, Graham DI. Beta A4 amyloid protein deposition in brain after head trauma. Lancet. 1991;338:1422-3.

64. Brohi K, Cohen MJ, Ganter MT, Schultz MJ, Levi M, Mackersie RC,et al. Acute coagulopathy of trauma: hypoperfusion induces systemic anticoagulation and hyperfibrinolysis. J Trauma 2008;64:12 I I-7.

65. Mattiasson G, Shamloo M, Gido G, Mathi K, Tomasevic G, Yi S,et al. Uncoupling protein-2 prevents neuronal death and diminishes brain dysfunction after stroke and brain trauma. Nat Med 2003;9:1062-8.

66. Cosgriff N, Moore EE, Sauaia A, Kenny-Moynihan M, Burch JM, Galloway B. Predicting life-threatening coagulopathy in the massively transfused trauma patient: hypothermia and acidoses revisited. J Trauma 1997;42:857-6I.

67. Spahn DR, Bouillon B, Cerny V, Coats TJ, Duranteau J, Fernández-Mondéjar E,et al. Management of bleeding and coagulopathy following major trauma: an updated Europeanguideline. Crit Care 2013;17:R76.

68. Binder LM, Rohling ML, Larrabee GJ. A review of mild head trauma. Part I: Meta-analytic review of neuropsychological studies. J Clin Exp Neuropsychol 1997;19:421-31.

69. Rossaint R, Bouillon B, Cerny V, Coats TJ, Duranteau J, Fernández-Mondéjar E, et al. Crit Care. Management of bleeding following major trauma: an updated European guideline. Crit Care 20I0; I4(2):R52.

70. Acosta JA, Yang JC, Winchell RJ, Simons RK, Fortlage DA, Hollingsworth-Fridlund P, et al. Lethal injuries and time to death in a level I trauma center. J Am Coll Surg 1998; |86:528-33.

7I. Martinowitz U, Kenet G, Segal E, Luboshitz J, Lubetsky A, Ingerslev J, et al. Recombinant activated factor VII for adjunctive hemorrhage control in trauma. J Trauma 200I;51:43I-8.

72. Border JR, Hassett J, LaDuca J, Seibel R, Steinberg S, Mills B, et al. The gut origin septic states in blunt multiple trauma (ISS=40) in the ICU. Ann Surg 1987 Oct;206(4):427-48.

73. Ledingham IM, Watt I. Influence of sedation on mortality in critically ill multiple trauma patients. Lancet 1983;1:1270.

74. Schöchl H, Nienaber U, Hofer G, Voelckel W, Jambor C, Scharbert G, et al. Goal-directed coagulation management of major trauma patients using thromboelastometry (ROTEM)-guided administration of fibrinogen concentrate and prothrombin complex concentrate. Crit Care 2010; 14:R55.

75. Huber-Wagner S, Lefering R, Qvick LM, Körner M, Kay MV, Pfeifer KJ, et al.; Working Group on Polytrauma of the German Trauma Society. Collaborators (4) Seekamp A, Ruchholtz S,Lefering R, Paffrath T. Effect of whole-body CT during trauma resuscitation on survival: a retrospective, multicentre study. Lancet 2009;373:|455-6I.

76. Maegele M, Lefering R, Yucel N, Tjardes T, Rixen D, Paffrath T,et al. Early coagulopathy in multiple injury: an analysis from the German Trauma Registry on 8724 patients. Injury 2007;38: 298-304.

77. Rimel RW, Giordani B, Barth JT, Jane JA. Moderate head injury: completing the clinical spectrum of brain trauma. Neurosurgery 1982; I I:344-5I.

78. Cotanche DA. Regeneration of hair cell stereociliary bundles in the chick cochlea following severe acoustic trauma. Hear Res 1987;30:181-95.

79. Bramlett HM, Dietrich WD. Pathophysiology of cerebral ischemia and brain trauma: similarities and differences. J Cereb Blood Flow Metab 2004;24:133-50. 
Appendix I. The top 100 cited articles in traumatology (continuation)

\section{Rank Article}

80. Rogers FB, Cipolle MD, Velmahos G, Rozycki G, Luchette FA. Practice management guidelines for the prevention of venous thromboembolism in trauma patients: the EAST practice management guidelines work group. J Trauma 2002;53:142-64.

8I. Konttinen YT, Ainola M, Valleala H, Ma J, Ida H, Mandelin J,et al. Analysis of I6 different matrix metalloproteinases (MMP-I to MMP-20) in the synovial membrane: different profiles in trauma and rheumatoid arthritis. Ann Rheum Dis 1999;58:691-7.

82. CRASH-2 collaborators (558 researchers), Roberts I, Shakur H, Afolabi A, Brohi K, Coats T, Dewan Y, et al The importance of early treatment with tranexamic acid in bleeding trauma patients: an exploratory analysis of the CRASH-2 randomised controlled trial. Lancet 201 I;377:1096-I0I,II0I.el-2.

83. Nichols RL, Smith JW, Klein DB, Trunkey DD, Cooper RH, Adinolfi MF,et al. Risk of infection after penetrating abdominal trauma. N Engl J Med 1984;3 I I:1065-70.

84. Nathens AB, Jurkovich GJ, Maier RV, Grossman DC, MacKenzie EJ, Moore M, et al. Relationship between trauma center volume and outcomes. JAMA 200I;285:II64-7I.

85. Annegers JF, Grabow JD, Kurland LT, Laws ER Jr. The incidence, causes, and secular trends of head trauma in Olmsted County, Minnesota, 1935-1974. Neurology 1980;30:912-9.

86. Brohi K, Cohen MJ, Davenport RA. Acute coagulopathy of trauma: mechanism, Identification and effect. Curr Opin Crit Care 2007; 13: 680-5.

87. Rugeri L, Levrat A, David JS, Delecroix E, Floccard B, Gros A,et al. Diagnosis of early coagulation abnormalities in trauma patients by rotation thrombelastography. J Thromb Haemost 2007;5:289-95.

88. Holbrook TL, Anderson JP, Sieber WJ, Browner D, Hoyt DB. Outcome after major trauma: I2-month and I8-month follow-up results from the Trauma Recovery Project. J Trauma 1999;46:765-7I.

89. Croce MA, Fabian TC, Menke PG, Waddle-Smith L, Minard G, Kudsk KA, et al. Nonoperative management of blunt hepatic trauma is the treatment of choice for hemodynamically stable patients. Results of a prospective trial. Ann Surg 1995;221:744-53.

90. Johansen K, Daines M, Howey T, Helfet D, Hansen ST Jr. Objective criteria accurately predict amputation following lower extremity trauma. J Trauma 1990;30:568-72.

91. Cales RH, Trunkey DD. Preventable trauma deaths. A review of trauma care systems development. JAMA 1985;254:1059-63.

92. Dietz HP, Lanzarone V. Levator trauma after vaginal delivery. Obstet Gynecol 2005; 106:707-12.

93. Morris JA Jr, Eddy VA, Blinman TA, Rutherford EJ, Sharp KW. The staged celiotomy for trauma. Issues in unpacking and reconstruction. Ann Surg 1993;217:576-84.

94. Smith DH, Chen XH, Pierce JE, Wolf JA, Trojanowski JQ, Graham DI, et al. Progressive atrophy and neuron death for one year following brain trauma in the rat. J Neurotrauma 1997; I4: 7I5-27.

95. Shackford SR, Hollingworth-Fridlund P, Cooper GF, Eastman AB. The effect of regionalization upon the quality of trauma care as assessed by concurrent audit before and after institution of a trauma system: a preliminary report. J Trauma 1986;26:8I2-20.

96. Kluft C, Verheijen JH, Jie AF, Rijken DC, Preston FE,et al. The postoperative fibrinolytic shutdown: a rapidly reverting acute phase pattern for the fast-acting inhibitor of tissue-type plasminogen activator after trauma. Scand J Clin Lab Invest 1985;45: 605-10.

97. Pape HC, Auf'm'Kolk M, Paffrath T, Regel G, Sturm JA, Tscherne H. Primary intramedullary femur fixation in multiple trauma patients with associated lung contusion-a cause of posttraumatic ARDS? J Trauma 1993;34:540-7.

98. Mortimer JA, van Duijn CM, Chandra V, Fratiglioni L, Graves AB, Heyman A, et al. Head trauma as a risk factor for Alzheimer's disease: a collaborative re-analysis of case-control studies. EURODEM Risk Factors Research Group. Int J Epidemiol 199I;20 Suppl 2:S28-35.

99. Balogh Z, McKinley BA, Cocanour CS, Kozar RA, Valdivia A, Sailors RM, et al. Supranormal trauma resuscitation causes more cases of abdominal compartment syndrome. Arch Surg 2003;138:637-42. neuroprotective opportunities. Brain Res Rev 2002;39:55-73. 